\title{
Energy saving analysis of air fan motor in power plant boiler controlled by variable frequency drive
}

\author{
Pramono Mukti Wibowo, Muhamad Haddin, Arief Marwanto \\ Department of Electrical and Computer Engineering, Sultan Agung Islamic University, Semarang, Indonesia
}

\begin{tabular}{l} 
Article Info \\
\hline Article history: \\
Received Jan 29, 2021 \\
Revised Sep 16, 2021 \\
Accepted Sep 23, 2021 \\
\hline
\end{tabular}

\section{Keywords:}

Forced draft fan

Primary air fan

Saving opportunity

Variable frequency drive

\begin{abstract}
A reporting of Energy Audit in 2018 by LEMTEK UI has reported that air fan system currently used in Power Plant of PLTU Tanjung Jati B Jepara is inefficient, energy efficiency in FDF is only $32 \%$ and PAF efficiency is $49.01 \%$. Inefficiency of the air fan system is an impacted there are waste of electric energy amount of $13,352,929 \mathrm{KWh}(13,35 \mathrm{GWh})$ a year with a financial loss of IDR 13,352,929,140. To overcome this condition, variable frequency drive (VFD) is installed which adjusted air flow as needed so that energy waste can be reduced. MATLAB simulation is proposed to analyze the VFD method. The result shows that by using VFD, 8,233,573.444 KWh $(8.45 \mathrm{GWh})$ can be saved a year. Total cost benefits are IDR $8,233,573,444$ as $32.1 \%$ of saving cost. Efficiency of FDF is $72.57 \%$ and PAF is $66.84 \%$.
\end{abstract}

This is an open access article under the CC BY-SA license.

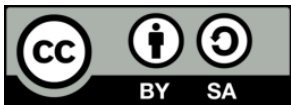

\section{Corresponding Author:}

Pramono Mukti Wibowo

Department Postgraduate of Electrical Engineering

Universitas Islam Sultan Agung Semarang

Jl. Kaligawe Raya No.KM 4, Terboyo Kulon, Kec. Genuk, Semarang, Jawa Tengah, Indonesia

Email: pram.mukti@std.unissula.ac.id

\section{INTRODUCTION}

The report of energy audits and performance tests in Power Plant Tanjung Jati B Jepara year 2018 shows that the air fan of boiler system is unefficient and over air supply, energy efficiency in the forced draft fan (FDF) () is only $32 \%$ and the primary air fan (PAF) efficiency is $49.01 \%$. The flow rate capability of FDF is 1440 tons/day but the flow rate used is 512 tons/day and the flow rate of PAF is 450 tons/day but 197.4 tons/day is used in operation [1].

As a result, in this condition, there are waste of electrical energy in the electric motor operation. Moreover, it also resulted in financial losses [1]. According to the calculation data from the audit team, with the assumption that variable frequency drive (VFD) has been installed, the electric power loss in the FDF motor is $998.63 \mathrm{KWh}$ or $6,391,246.93 \mathrm{KWh} /$ year and in the PAF motor is $1,087.76 \mathrm{KWh}$ or $6,961,684.21$ $\mathrm{KWh} /$ year[1]. If calculated into rupiah $(1 \mathrm{KWh}=$ IDR 1000), the total financial loss is IDR 13,352,929,140 a year. The calculation is based on an FDF and PAF which integrated works together during 7286 hours[1]. To overcome unefficiency and over air supply, VFD is proposed. VFD regulates the air supply by adjusting the motor speed so that there is no excess air and its use is as needed, regulation of the motor by VFD also causes a decrease in the electrical power, therefore electric energy can be saved and efficiency of motors will be increased [2]-[15]. 


\section{RESEARCH METHOD}

The FDF and PAF VFD systems work in an integrated manner to supply air into the boiler, FDF provides air for the combustion process while PAF produces hot air to push coal into the combustion chamber. In existing system the air supply is higher than needs, so it is necessary to reduce the air supply by lowering the power using a VFD. In this way, the frequency, current and voltage in both of motors will also decrease and reduce the use of electrical power. FDF and PAF systems using VFD are shown in Figure 1 [6], [16]-[21]. The VFD block scheme is shown in Figure 2 [16], [20], [22]-[26].

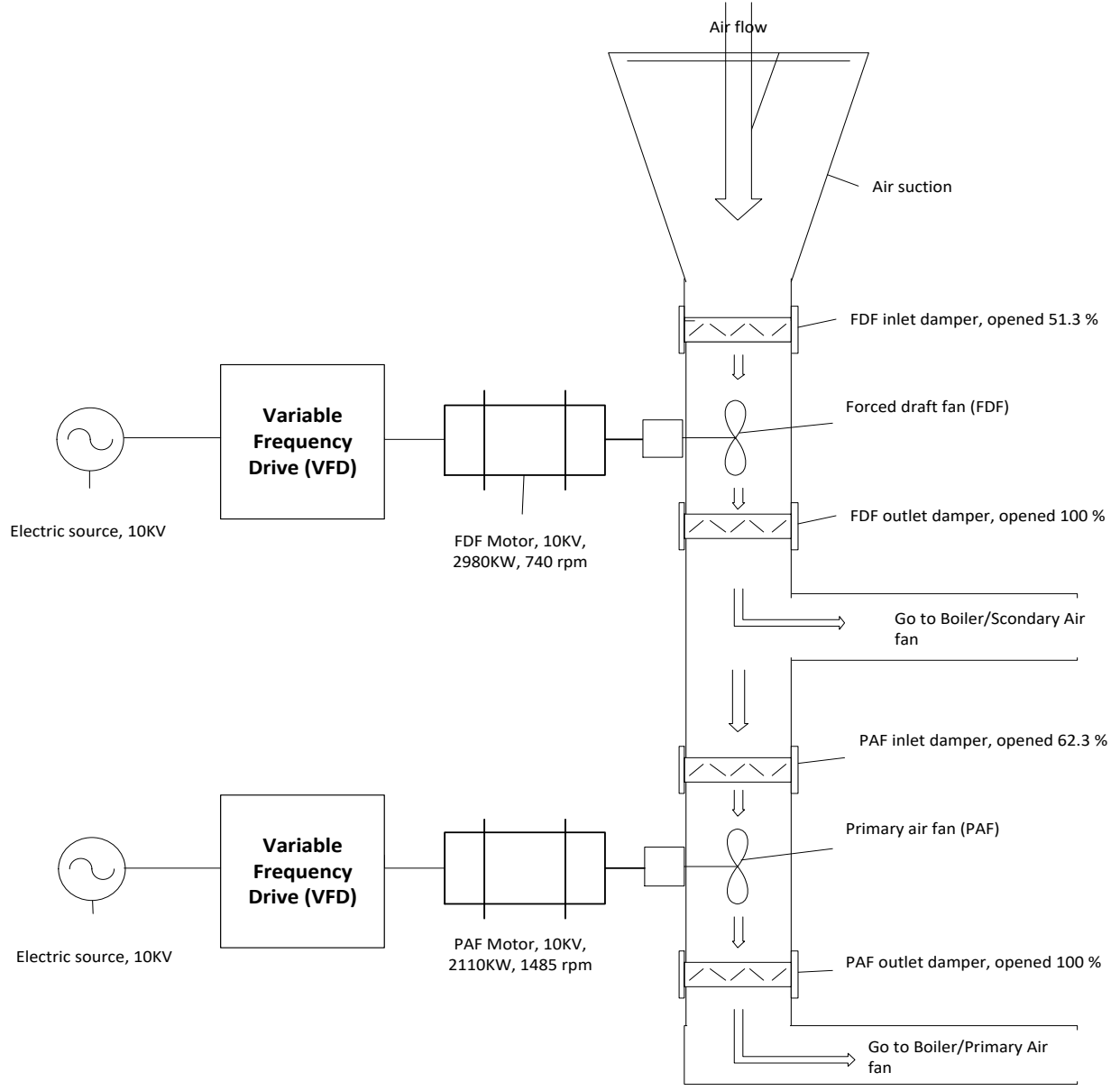

Figure 1. FDF and PAF System Model with VFD

Figure 2 shows the system model of the VFD circuit. The circuit consists of two parts of VFD FDF and PAF which are composed of block with respective functions. The blocks in the Figure 2 are entire VFD section which will be outlined in the MATLAB/Simulink circuit. VFD is simulated in MATLAB/Simulink shown in Figure 3 [6], [24], [26], [27]. Figure 3 is a simulation circuit of the VFD to drive the FDF and PAF motors. There are 2 VFD combined to drive 2 motors at once. In principle, the two parts of VFD have a similar work, the difference in parameters of motors. The supply voltage first passes through the rectifier unit where it is converted from AC to DC voltage. The DC voltage enters into filter to reduce the harmonic distortion during AC to DC conversion. Main part is an inverter which consists of six insulated gate bipolar transistor (IGBT) to convert DC to AC. Various frequency are carried out by using the pulse width modulation (PWM) method in the inverter device, this device gives a combination of sine and saw signal pulses that vary according to the required needs. Speed of the motor depend on adjusted frequency. Therefore, by adjusting the frequency through to the VFD we can control the speed of the induction motor in (1) [8], [13], [18], [28]-[30]. 


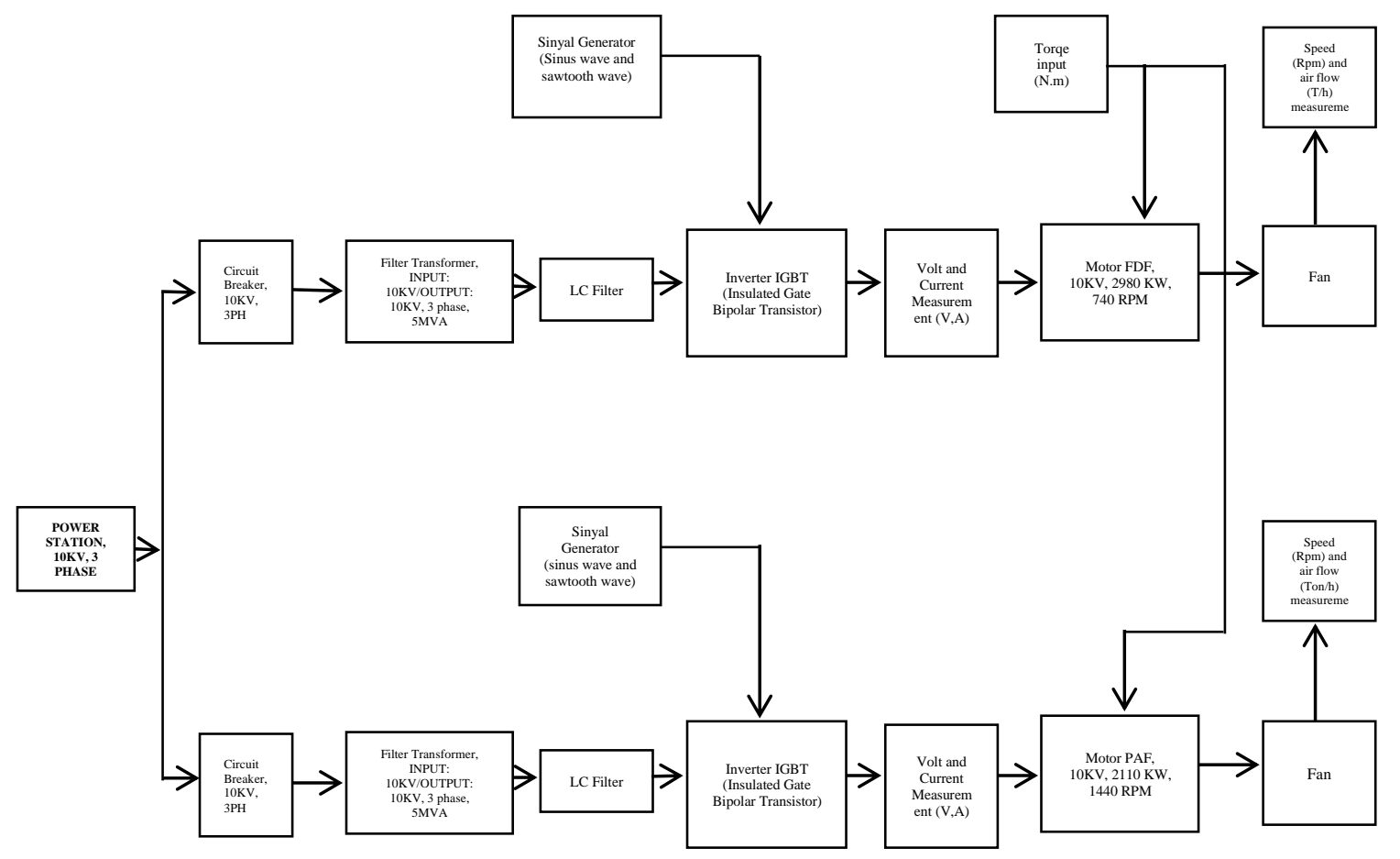

Figure 2. VFD block schematic

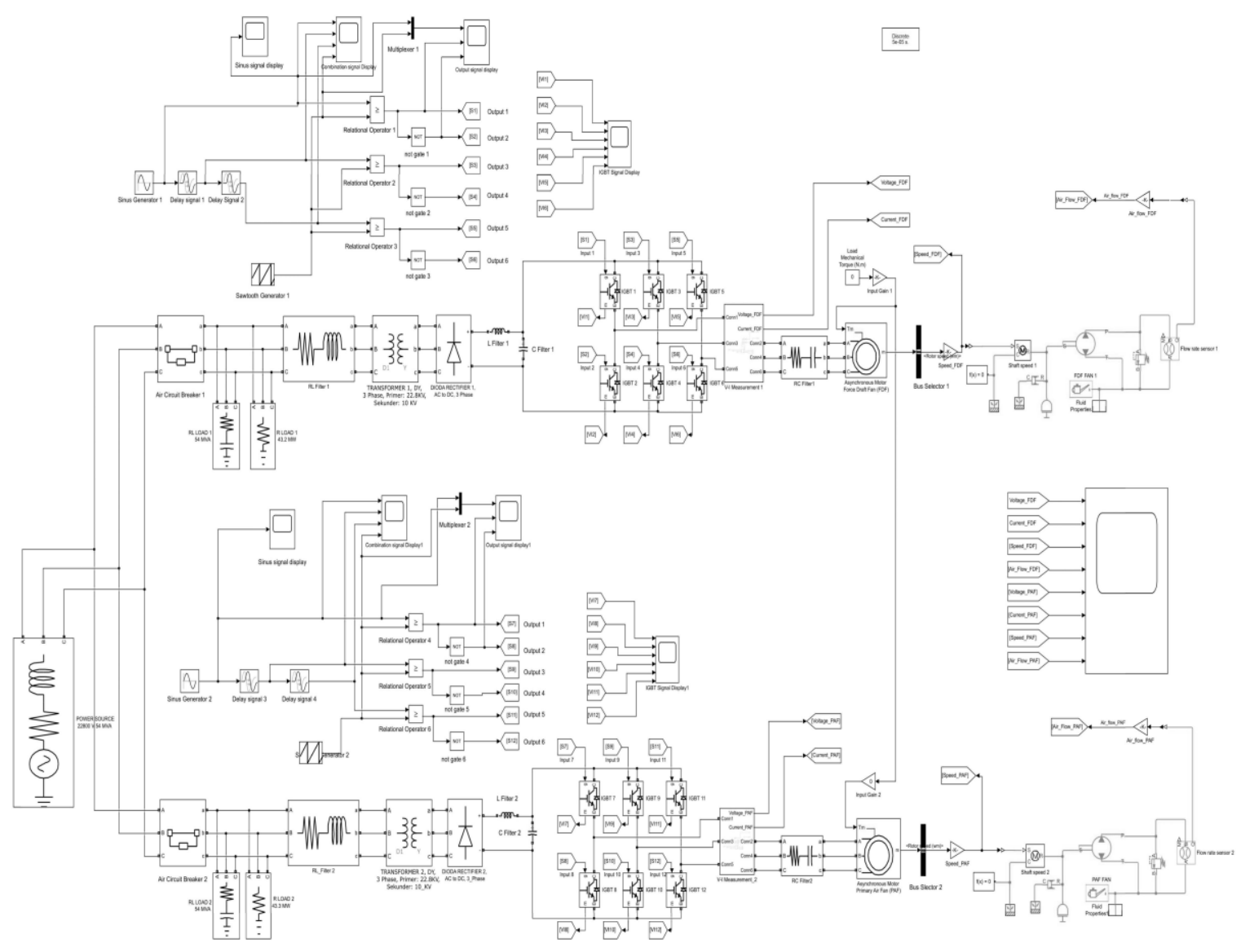

Figure 3. VFD simulation circuit 
Speed $($ rpm $)=($ Frequency $x 120) /$ pole

where:

Frequency: frequency in $\mathrm{Hz}$

Pole: number of electric poles on the motor stator

Electrical power of VFD is calculated based on the load motors by taking voltage and current as shown in (2) [13], [30].

$$
P=\sqrt{3} \cdot \text { V.I.Cos } p h i
$$

where:

P: electrical power at load $(\mathrm{W})$

$\mathrm{V}$ : voltage at load $(\mathrm{V})$

I: electric current at load (A)

Cos phi: power factor at load

The financial cost calculation of electric power based on the amount of power during running hours as shown in (3) [1], [12]

$$
\text { Financial cost }=P x \text { Running hours } x \text { Price per } K W H
$$

where:

P: electrical power $(\mathrm{W})$

Running hours: VFD working duration in hours

Price per KWh: terms of electricity price per KWh

Saving opportunity is the difference between the installed device power and the device power in a simulation as shown in (4) [1], [12].

$$
\text { Saving opportunity }=\text { real power }- \text { simulated power }
$$

where:

Real power: total power of FDF and PAF for 1 year

Simulation power: total power of FDF and PAF in simulation for 1 year

Break even point is the period of investment return costs based on the value of savings obtained hours as shown in (5) [1], [12].

$$
\text { Break even point }=\text { Investment cost } / \text { finacial savings opportunity }
$$

where:

Investment cost: VFD installation fee

Financial saving opportunity: VFD savings value obtained in 1 year

Efficiency of FDF and PAF is comparison between total power output and total power input as shown in (6) [1], [12].

$$
\eta=\frac{\mathrm{dP} \cdot \mathrm{Q}}{\sqrt{3} \cdot \mathrm{V} \cdot \mathrm{I} \cdot \mathrm{COS} \text { phi }} \times 100 \%
$$

where:

$\eta$ : fan efficiency

dP: differential pressure

Q: air debit

$\mathrm{V}$ : voltage

I: current

Cos phi: power factor

The parameters entered into the VFD are shown in Table 1 [12], [13] 
Table 1. VFD parameters

\begin{tabular}{|c|c|c|c|c|c|}
\hline No. & Block name & Input parameter & No. & Block name & Input parameter \\
\hline 1 & Power source & $\begin{array}{l}3 \text { Phase } \\
\text { Configuration: } \mathrm{Yg} \\
\text { Vrms: } 22800 \\
\text { Frequency }(\mathrm{Hz}): 50\end{array}$ & 14 & $\begin{array}{l}\text { Relational } \\
1,2,3,4,5,6\end{array}$ & $\begin{array}{l}\text { Relational: >= } \\
\text { Output data type: Boolean }\end{array}$ \\
\hline 2 & Air circuit breaker 1,2 & $\begin{array}{l}3 \text { Phase } \\
\text { Breaker resistance: } 0.01 \\
\text { Ohm }\end{array}$ & 15 & Not gate $1,2,3,4,5,6$ & $\begin{array}{l}\text { Operator: not } \\
\text { Output data type: Boolean }\end{array}$ \\
\hline 3 & RL load 1,2 & $\begin{array}{l}\text { Configuration: Y } \\
\text { (grounded) } \\
\text { Vrms: } 22800 \\
\text { Frequency: } 50 \\
\text { Active power: } 54 \mathrm{e} 6\end{array}$ & 16 & $\begin{array}{l}\text { IGBT } \\
1,2,3,4,5,6,7,8,9,10,11,12\end{array}$ & $\begin{array}{l}\text { Internal resistance: } 1 \mathrm{e}-3 \\
\text { Snubber resistance: } 1 \mathrm{e} 5\end{array}$ \\
\hline 4 & $\mathrm{R}$ load 1,2 & $\begin{array}{l}\text { Configuration: } \mathrm{Y} \\
\text { (grounded) } \\
\text { Vrms: } 22800 \\
\text { Frequency: } 50 \\
\text { Active power: } 43,2 \mathrm{e} 6\end{array}$ & 17 & V-I measurement 1,2 & $\begin{array}{l}\text { Measurement: phase to phase } \\
\text { Current measurement: yes }\end{array}$ \\
\hline 5 & RL filter 1,2 & $\begin{array}{l}\text { Branch type: } \mathrm{RL} \\
\text { Resistance: } 0.1 \mathrm{e}-3 \\
\text { Inductance: } 20 \mathrm{e} 8\end{array}$ & 18 & RC Filter 1,2 & $\begin{array}{l}\text { Resistance: } 0,5 \mathrm{Ohm} \\
\text { Capacitance: } 0,1 \mathrm{~F}\end{array}$ \\
\hline 6 & Transformer 1,2 & $\begin{array}{l}\text { Connection: DY } \\
\text { Nominal power: } 6 \mathrm{e} 6 \\
\text { Primary voltage: } 22,8 \mathrm{e} 6 \\
\text { Secondary voltage: } 10 \mathrm{e} 6\end{array}$ & 19 & Asynchronous motor FDF & $\begin{array}{l}\text { rotor type: squirrel cage } \\
\text { Mechanical input: Torque Tm, } 0 \\
\text { Nominal power: } 2052220 \mathrm{~W} \\
\text { Voltage: } 10000 \mathrm{~V} \\
\text { Frequency: } 50 \mathrm{~Hz} \\
\text { Pole: } 8 \\
\text { Slip: } 0,0133\end{array}$ \\
\hline 7 & Dioda rectifier & $\begin{array}{l}\text { Bridge arms: } 3 \\
\text { Device: IGBT/Dioda }\end{array}$ & 20 & Asynchronous motor PAF & $\begin{array}{l}\text { Rotor type: Squirrel cage } \\
\text { Mechanical input: Torque Tm, } 0 \\
\text { Nominal power: } 1467630 \mathrm{~W} \\
\text { Voltage: } 10000 \mathrm{~V} \\
\text { Frequency: } 50 \mathrm{~Hz} \\
\text { Pole: } 4 \\
\text { Slip: } 0,0133\end{array}$ \\
\hline 8 & L filter 1,2 & Inductance: $800 \mathrm{H}$ & 21 & Bus selector 1,2 & Mechanical motor speed (Wm) \\
\hline 9 & C filter 1,2 & Capacitance: $75000 \mathrm{~F}$ & 22 & Shaft speed 1,2 & Velocity source, torque sensor \\
\hline 10 & Sinus generator 1,2 & $\begin{array}{l}\text { Sine type: time based } \\
\text { amplitude: } 1 \\
\text { Frequency: } 2 * \text { pi } * 50 \\
(0-50 \mathrm{~Hz}) \\
\text { Phase: } 120 \mathrm{rad} \\
\text { Phase: } 0\end{array}$ & 23 & FDF fan & $\begin{array}{l}\text { Displacement: } 5 \mathrm{e}-06 \mathrm{~m}^{\wedge} 3 / \mathrm{rad} \\
\text { Nominal shaft angular velocity: } \\
750 \\
\text { Nominal fluid density: } 14000000 \\
\text { No Load Torque: } 10,9\end{array}$ \\
\hline 11 & Delay signal 1,3 & $\begin{array}{l}\text { Time delay: } 0,0067 \\
\text { Initial buffer size: } 1024\end{array}$ & 24 & PAF fan & $\begin{array}{l}\text { Displacement: } 5 \mathrm{e}-06 \mathrm{~m}^{\wedge} 3 / \mathrm{rad} \\
\text { Nominal shaft angular velocity: } \\
1446 \\
\text { Nominal fluid density: } 1400 \\
\text { No load torque: } 0 \\
\text { Sinus sional disnlay }\end{array}$ \\
\hline 12 & Delay signal 2,4 & $\begin{array}{l}\text { Time delay: } 0,013 \\
\text { Initial buffer size: } 1024\end{array}$ & 25 & Scope display & $\begin{array}{l}\text { Combination signal display } \\
\text { Output signal display } \\
\text { IGBT signal display } \\
\text { Result signal display }\end{array}$ \\
\hline 13 & Sawtooth generator 1,2 & $\begin{array}{l}\text { Frequency: } 1 \mathrm{e} 3 \\
\text { Phase: } 120\end{array}$ & 26 & Load mechanical torque & $0-10,9 \mathrm{Nm}$ \\
\hline
\end{tabular}

\section{RESULTS AND DISCUSSION}

\subsection{VFD output signal}

Simulation VFD using MATLAB/Simulink results of the signal form is obtained as shown in Figure 4. Figure 4 are output signal of VFD FDF and PAF, each signal showing voltage, current, motor speed and airflow. Simulation is done by vary the input frequency from $1 \mathrm{~Hz}$ to $50 \mathrm{~Hz}$. The input frequency is carried out in the signal generator section. The sample frequency given to the simulation starts from $2 \mathrm{~Hz}$ to $50 \mathrm{~Hz}$ in increments of $2 \mathrm{~Hz}$. Every increase in frequency in the generator signal will be followed by an increase in motor voltage, speed and air flow rate. The data from the simulation results are shown in Table 2. 

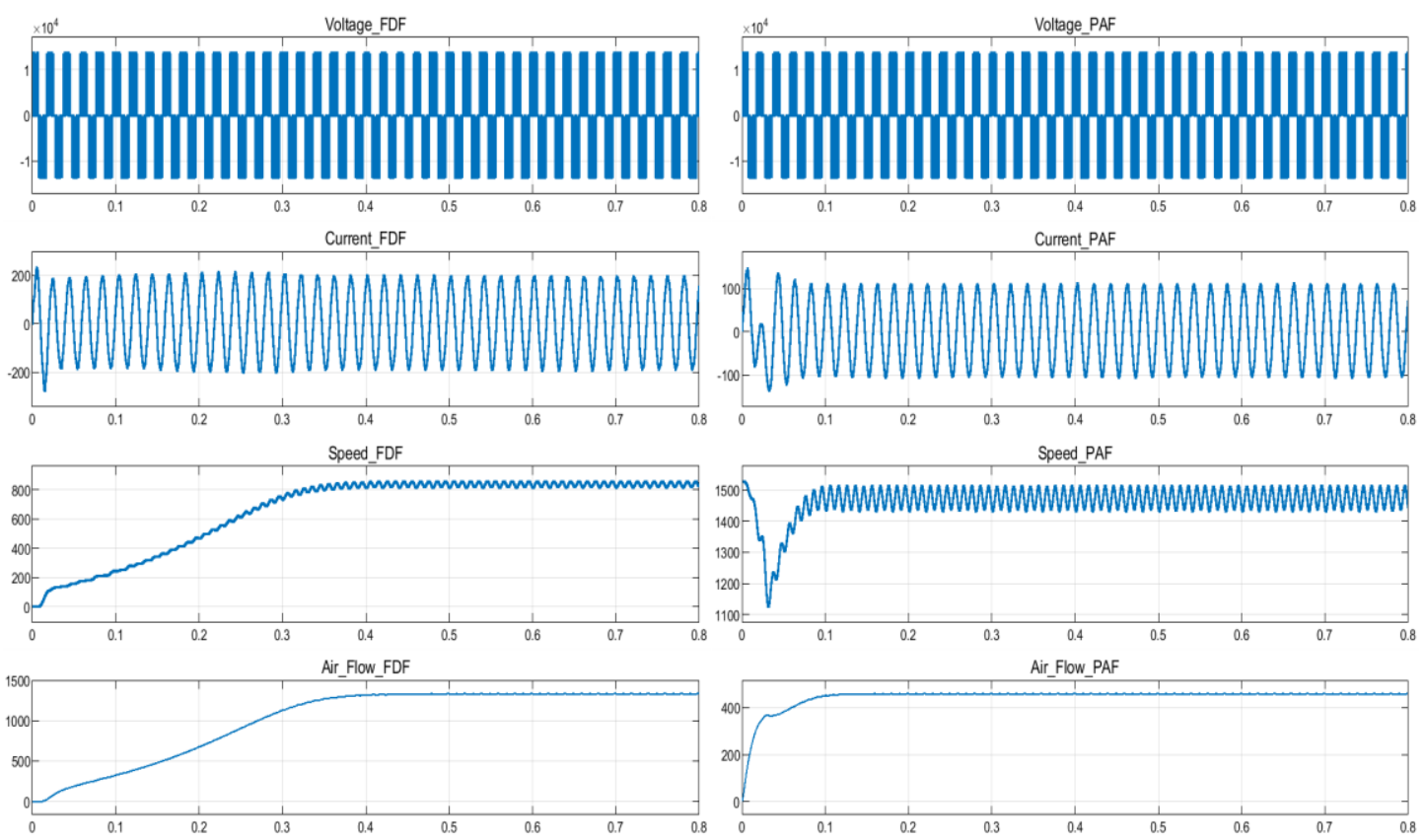

Figure 4. VFD output signal

Table 2 shows the lowest input frequency for VFD is $2 \mathrm{~Hz}$ and the highest is $50 \mathrm{~Hz}$, the lowest FDF voltage is $2892 \mathrm{~V}$ and the highest is $9826 \mathrm{~V}$, the current ranges from 29 A to $139 \mathrm{~A}$, the lowest motor speed is $45 \mathrm{Rpm}$ and the highest is $762 \mathrm{Rpm}$ and air flow obtained the lowest 77 Tons/hour to the highest 1661 Tons/hour. PAF output obtained the lowest voltage is $2880 \mathrm{~V}$ and the highest is $9816 \mathrm{~V}$, the current ranges from $27 \mathrm{~A}$ to $98 \mathrm{~A}$, the lowest motor speed is $295 \mathrm{Rpm}$ and the highest is $1363 \mathrm{Rpm}$ and the lowest air flow rate is $90 \mathrm{Ton} /$ hour and the highest is $526 \mathrm{Ton} / \mathrm{hour}$. Variation of frequency followed by voltage of the FDF and PAF motors is shown in Figure 5.

Table 2. VFD output value

\begin{tabular}{|c|c|c|c|c|c|c|c|c|c|}
\hline \multirow[b]{2}{*}{ No } & \multirow[b]{2}{*}{ Freq. input } & \multicolumn{4}{|c|}{ FDF } & \multicolumn{4}{|c|}{ PAF } \\
\hline & & $\begin{array}{c}\text { Voltage } \\
(\mathrm{V})\end{array}$ & $\begin{array}{c}\text { Current } \\
\text { (A) }\end{array}$ & $\begin{array}{l}\text { Speed } \\
(\mathrm{Rpm})\end{array}$ & $\begin{array}{l}\text { Air Flow } \\
\text { (Ton/hr) }\end{array}$ & $\begin{array}{c}\text { Voltage } \\
\text { (V) }\end{array}$ & $\begin{array}{c}\text { Current } \\
\text { (A) }\end{array}$ & $\begin{array}{l}\text { Speed } \\
(\mathrm{Rpm})\end{array}$ & $\begin{array}{l}\text { Air Flow } \\
\text { (Ton/hr) }\end{array}$ \\
\hline 1 & 2 & 2892 & 29 & 45 & 77 & 2880 & 27 & 295 & 90 \\
\hline 2 & 4 & 3828 & 51 & 81 & 139 & 3924 & 41 & 294 & 81 \\
\hline 3 & 6 & 4991 & 74 & 105 & 181 & 4993 & 54 & 328 & 94 \\
\hline 4 & 8 & 5500 & 94 & 147 & 257 & 5497 & 67 & 378 & 111 \\
\hline 5 & 10 & 5958 & 110 & 174 & 311 & 5959 & 77 & 430 & 130 \\
\hline 6 & 12 & 6347 & 121 & 243 & 440 & 6334 & 86 & 485 & 149 \\
\hline 7 & 14 & 6641 & 132 & 280 & 515 & 6629 & 94 & 537 & 169 \\
\hline 8 & 16 & 6917 & 137 & 312 & 589 & 6906 & 98 & 583 & 189 \\
\hline 9 & 18 & 7221 & 137 & 341 & 664 & 7207 & 98 & 626 & 210 \\
\hline 10 & 20 & 7562 & 131 & 370 & 741 & 7561 & 93 & 668 & 232 \\
\hline 11 & 22 & 7850 & 123 & 400 & 820 & 7842 & 87 & 713 & 255 \\
\hline 12 & 24 & 8057 & 139 & 438 & 897 & 8048 & 78 & 762 & 279 \\
\hline 13 & 26 & 8232 & 112 & 469 & 984 & 8216 & 69 & 814 & 303 \\
\hline 14 & 28 & 8442 & 100 & 503 & 1060 & 8429 & 59 & 870 & 328 \\
\hline 15 & 30 & 8586 & 93 & 534 & 1136 & 8570 & 51 & 927 & 352 \\
\hline 16 & 32 & 8713 & 82 & 569 & 1215 & 8706 & 42 & 984 & 375 \\
\hline 17 & 34 & 8858 & 70 & 601 & 1293 & 8842 & 36 & 1041 & 399 \\
\hline 18 & 36 & 9004 & 59 & 637 & 1378 & 8991 & 32 & 1099 & 421 \\
\hline 19 & 38 & 9137 & 58 & 671 & 1458 & 9124 & 31 & 1154 & 444 \\
\hline 20 & 40 & 9174 & 63 & 704 & 1531 & 9165 & 34 & 1208 & 465 \\
\hline 21 & 42 & 9394 & 73 & 734 & 1597 & 9381 & 40 & 1259 & 485 \\
\hline 22 & 44 & 9476 & 84 & 760 & 1657 & 9471 & 47 & 1305 & 503 \\
\hline 23 & 46 & 9515 & 95 & 781 & 1702 & 9500 & 54 & 1344 & 518 \\
\hline 24 & 48 & 9587 & 107 & 790 & 1722 & 9586 & 62 & 1368 & 528 \\
\hline 25 & 50 & 9826 & 118 & 762 & 1661 & 9816 & 70 & 1363 & 526 \\
\hline
\end{tabular}


Figure 5 shows the variation of input frequency in VFD from $2 \mathrm{~Hz}$ to $50 \mathrm{~Hz}$ followed by a voltage change which increases from $2880 \mathrm{~V}$ to $10000 \mathrm{~V}$. The variation of voltage followed the speed of the FDF and PAF motors is shown in Figure 6. It shows the various voltage followed by speed of the FDF and PAF motors. In the FDF motor, the lowest voltage is $2892 \mathrm{~V}$ followed by a motor speed of $45 \mathrm{Rpm}$, while the highest voltage is $9826 \mathrm{~V}$ followed by a motor speed of $762 \mathrm{Rpm}$. In the PAF motor, the lowest voltage is $2880 \mathrm{~V}$ followed by a motor speed of $295 \mathrm{Rpm}$ and the highest voltage is $9816 \mathrm{~V}$ followed by a motor speed of $1363 \mathrm{Rpm}$. The various speed of the FDF motor followed by air flow is shown in Figure 7.

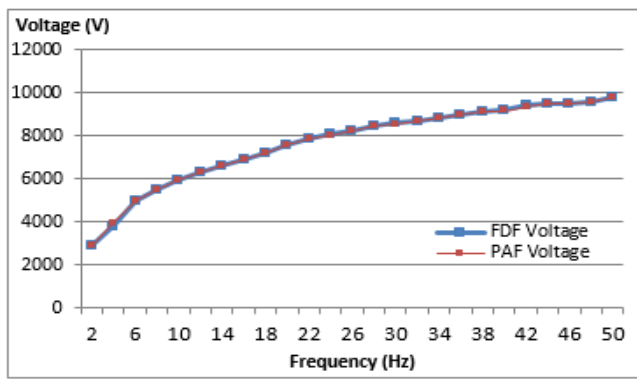

Figure 5. Correlation between various frequency and voltage

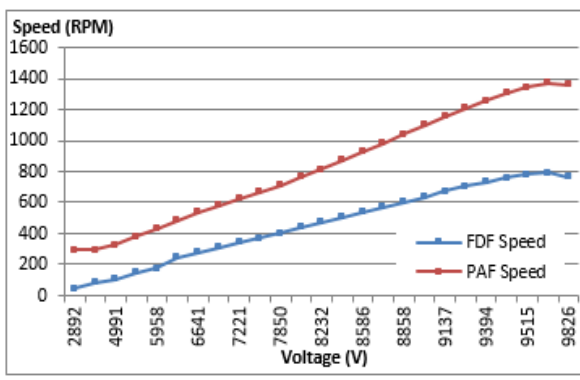

Figure 6. Correlation between various voltage and speed

Figure 7 shows the various speed of the FDF motor followed by air flow in the impeller fan which is the load on the motor. The lowest speed is $45 \mathrm{Rpm}$ followed air flow rate at $77 \mathrm{Ton} /$ hour and at the highest speed is $762 \mathrm{Rpm}$ followed air flow at $1661 \mathrm{Ton} /$ hour. The various speed of the PAF motor followed by air flow is shown in Figure 8. It shows the various speed of the PAF motor followed by air flow. The lowest speed is $298 \mathrm{Rpm}$ followed air flow rate at 90 Ton/hour and the highest speed is $762 \mathrm{Rpm}$ followed air flow at 1661 ton/hour.

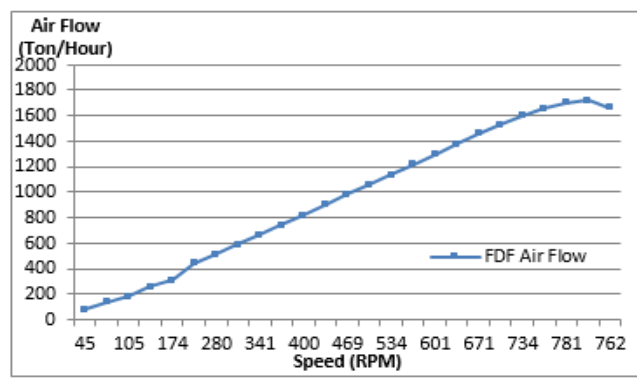

Figure 7. Correlation between various speed and air flow

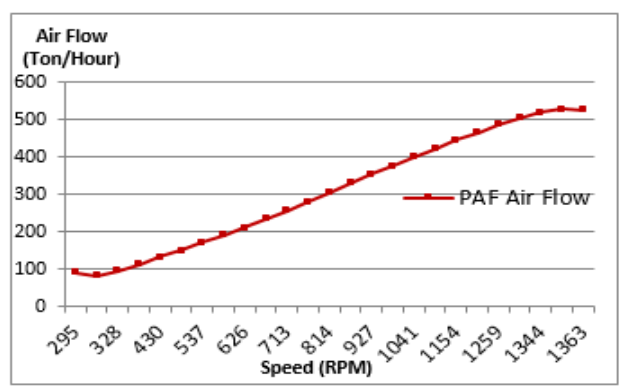

Figure 8. Correlation between various speed and air flow

\subsection{Power calculation}

The simulation power calculation is carried out based on the data from Table 2 VFD output value, from the data table searched flow rate value which is close to the actual flow rate value, the flow rate value is $984 \mathrm{Ton} / \mathrm{hr}$ for FDF and $232 \mathrm{Ton} / \mathrm{hr}$ for PAF. The flow rate will show the frequency, voltage, current and motor speed values, then the power will be calculated based on these values. Total running hours base on operation time a year is reduced by off time, the result is 7286 hours.

\subsubsection{Total power of FDF motor}

As shown (2) is used to calculate the value of the electric power in the FDF motor,

$$
\begin{aligned}
P & =\sqrt{3} \cdot \text { V.I.Cos phi } \\
& =\sqrt{3} \cdot 8232 \cdot 112 \cdot 0 \cdot 85 \\
& =1,355,777,472 \mathrm{~W} . \\
& =1,355 \cdot 78 \mathrm{KW}
\end{aligned}
$$


To calculate the electric power consumption for 1 hour then multiplied by an hour,

$$
\begin{aligned}
P & =1,355.78 \mathrm{KW} .1 \text { hour } \\
& =1,355.78 \mathrm{KWh}
\end{aligned}
$$

The duration of the running hours in 1 year are 7286 hours, therefore the total power is calculated by multiplying the KWh by the duration of the year,

$$
\begin{aligned}
P & =1,355.78 \mathrm{KWh} \times 7286 \text { hours } \\
& =9,878,213.08 \mathrm{KWh}
\end{aligned}
$$

As shown (3) is used to calculate operating costs by multiplying the total KWh by the price per KWh, Total operating costs;

$$
\begin{aligned}
& =9,878,213.08 \mathrm{KWh} \times I D R 1000 \\
& =I D R 9,878,213.080
\end{aligned}
$$

Efficiency of FDF calculated using (6),

$$
\eta=\frac{\mathrm{dP} \cdot \mathrm{Q}}{\mathrm{PFDF}} \times 100 \%
$$

Differential Pressure (dP) is pressure of flow rate FDF which opened damper 100\%, $1 \mathrm{KPa}$. Flow rate value is $984 \mathrm{Ton} / \mathrm{hr}$ or $273.34 \mathrm{~kg} / \mathrm{s}$.

$$
\begin{aligned}
& \eta=\frac{1 \times 273.34 \frac{\mathrm{kg}}{\mathrm{s}} \times 60 \text { second } \times 60 \text { minute } \times 7286 \text { hours }}{9,878,213,080(\mathrm{Wh})} \times 100 \% \\
& \eta=72.57 \%
\end{aligned}
$$

\subsubsection{Total power of PAF motor}

As shown (2) is used to calculate the value of the electric power in the PAF motor,

$$
\begin{aligned}
P & =\sqrt{3} \cdot \text { V.I.Cos phi } \\
& =\sqrt{3} \cdot 7561 \cdot 93 \cdot 0.85 \\
& =1,034,015,896 \mathrm{~W} . \\
& =1,034,016 \mathrm{KW}
\end{aligned}
$$

To calculate the electricity consumption for 1 hour, it is multiplied by an hour;

$$
\begin{aligned}
P & =1,034,016 \mathrm{KW} .1 \text { hour } \\
& =1,034,016 \mathrm{KWh}
\end{aligned}
$$

The duration of running hours in 1 year is 7286 hours, therefore the total power is calculated by multiplying the KWh by the duration of the year. Then it is obtained,

$$
\begin{aligned}
P & =1,034,016 \mathrm{KWh} \times 7286 \text { hours } \\
& =7,533,840,576 \mathrm{KWh}
\end{aligned}
$$

As shown (3) is used to calculate operating costs by multiplying the total KWh by the price per KWh, Total operating costs,

$$
\begin{aligned}
& =7,533,840,576 \mathrm{KWh} \times I D R 1,000 \\
& =I D R 7,533,840,576
\end{aligned}
$$

PAF efficiency calculated using (6),

$$
\eta=\frac{\mathrm{dP} \cdot \mathrm{Q}}{\mathrm{PFDF}} \times 100 \%
$$


Differential Pressure (dP) is pressure of flow rate FDF which opened damper 100\%, $3 \mathrm{KPa}$. Flow rate value is $232 \mathrm{Ton} / \mathrm{hr}$ or $644 \mathrm{~kg} / \mathrm{s}$.

$$
\begin{aligned}
& \eta=\frac{3 \times 64 \frac{\mathrm{kg}}{\mathrm{s}} \times 60 \text { second } \times 60 \text { minute } \times 7286 \text { hours }}{7,533,840,576(\mathrm{Wh})} \times 100 \% \\
& \eta=66.84 \%
\end{aligned}
$$

\subsection{Savings opportunities}

Savings opportunities is calculated using (4), existing motor power minus simulated motor power. The existing motor power is IDR $25,645,627.1 \mathrm{KWh} /$ year and the simulation power (FDF+PAF) is $17,412,053,656 \mathrm{KWh} /$ year.

$$
\begin{aligned}
& \text { Saving opportunity } \\
& =\text { actual power }- \text { simulation power } \\
& =25,645,627.1-17,412,053,656 \\
& =8,233,573,444 \mathrm{KWh} / \text { year }
\end{aligned}
$$

Financial savings opportunities:

$=8,233,573,444 \mathrm{KWh} \times \operatorname{IDR} 1000$

$=\operatorname{IDR} 8,233,573,444$

The opportunity for saving electrical power in a simulation is $8,233,573,444 \mathrm{KWh} / \mathrm{year}$ or in a percentage of $32.1 \%$. Financially, the cost savings was IDR $8,233,573,444$

\subsection{Break even point}

\begin{tabular}{|c|c|c|c|c|c|c|c|}
\hline \multirow{2}{*}{ No } & \multirow{2}{*}{ Parameter } & \multicolumn{2}{|c|}{ Actual system } & \multicolumn{2}{|c|}{ Simulation system } & \multicolumn{2}{|c|}{ Saving opportunity } \\
\hline & & Motor FDF & Motor PAF & Motor FDF & Motor PAF & Motor FDF & Motor PAF \\
\hline 1 & Running hours (hour) & 7,286 & 7,286 & 7,286 & 7,286 & & \\
\hline 2 & Flow rate (Ton/hour) & 967.5 & 242.85 & 984 & 255 & & \\
\hline 4 & Voltage (Vrms) & $9,955.62$ & $9,955.62$ & 8,232 & 7,561 & & \\
\hline 5 & Current (Irms) & 174.22 & 123.22 & 112 & 93 & & \\
\hline 6 & Speed motor(Rpm) & 740 & 1475 & 469 & 713 & & \\
\hline 8 & $\begin{array}{l}\text { Total power each motor } \\
\text { (KWh/year) (Px7286) }\end{array}$ & $14,952,474.9$ & $10,693,152.2$ & $9,878,213.08$ & $7,533,840.57$ & $5,074,261.8$ & $2,344,372.5$ \\
\hline 9 & $\begin{array}{l}\text { Total power for } 2 \text { motors } \\
\text { (KWh/year) (PFDF+PPAF) }\end{array}$ & $25,645,627.1$ & & $17,412,053.656$ & & $8,233,573.444$ & \\
\hline 10 & Electric cost per KWh (IDR) & 1,000 & & 1,000 & & 1,000 & \\
\hline 13 & $\begin{array}{l}\text { Break even point (year) } \\
\text { (Total investation/saving } \\
\text { opportunity) }\end{array}$ & & & & & & \\
\hline 14 & Break even point (month) & & & & & & \\
\hline
\end{tabular}

Based on the investment cost for the installation of VFD FDF of IDR 2,500,000,000 and a PAF VFD investment of IDR 2,000,000,000 [33], then the Break Even Point can be calculated using (5).

$$
\begin{aligned}
\text { Break even point } & =\text { investment cost/savings cost per year } \\
& =4,500,000,000 / 8,233,573,444 \\
& =0.546 \text { years } \\
& =6.552 \text { months }
\end{aligned}
$$

A summary of the overall data obtained is shown in Table 3.

Table 3. Summary of research data result 


\section{CONCLUSION}

The consumption of electrical energy of FDF and PAF during 1 year without using a VFD is $25,645,627.1 \mathrm{KWh}$, while using a VFD is 17,412,053,656 KWh. So, the use of VFD is considered to be more efficient energy because of its lower electricity consumption. The opportunity for saving by using VFD is $8,233,573,444 \mathrm{KWh}$ or $32.1 \%$ and the cost advantage obtained is IDR $8,233,573,444$. Efficiency of FDF is increase to be $72.57 \%$ and PAF is $66.84 \%$.

\section{REFERENCES}

[1] M. E. Nasruddin, “Energy Audits and Performance Test of PLN Tanjung Jati B Unit 3 and 4,” Lembaga Teknologi Fakultas Teknik UI, Jakarta 10430 Indonesia, 2018, Unpublished.

[2] M. Sequeira and S. Alahakoon, "Energy Efficient Variable Speed Drives Empowered with Torque Estimation," Energy Procedia, vol. 160, no. 2018, pp. 194-201, 2019, doi:10.1016/j.egypro.2019.02.136.

[3] M. Marchesoni, Energy Efficiency in Electric Motors, Drives, Power Converters and Related Systems. Italy: MDPI, 2020.

[4] K. P. Lodhari, "Variable Voltage Variable Frequency Drive for Single-Phase Motor and its Application," International Journal of Science and Research, vol. 7, no. 9, pp. 624-628, 2018, doi: 10.21275/9091802.

[5] A. Fri, R. El Bachtiri, A. E. Ghzizal, and A. Naamane, "Triphase symmetrical cascaded multilevel inverter (5L ) for PV systems controlled by various multicarrier PWM strategies," Energy Procedia, vol. 62, pp. 543-554, 2014, doi: 10.1016/j.egypro.2014.12.416.

[6] M. Tariq and T. Iqbal, "Power Quality Improvement by using Multi-pulse AC-DC Converters for DC Drives: Modeling, Simulation and its Digital Implementation,” J. Electr. Syst. Inf. Technol., vol. 1, no. 3, pp. 255-265, 2014, doi: 10.1016/j.jesit.2014.12.007.

[7] A. Ali, "A Low cost modelling of the variable frequency drive optimum in industrial applications," vol. 2, no. 1, pp. 28-42, 2018, doi: 10.30521/jes.405774.

[8] S. Velicu, S. V. Paturca, and M. Covrig, "An Improvement of The Mechanic Eccentric Power Presser Dynamics by Using Variable Frequency Induction Motor Drives," IFAC Proceedings Volumes, vol. 40, no. 18, pp. 875-879, 2007, doi: 10.3182/20070927-4-RO-3905.00145.

[9] C. M. Burt, X. Piao, F. Gaudi, B. Busch, and N. F. N. Taufik, "Electric Motor Efficiency under Variable Frequencies and Loads," Journal of Irrigation and Drainage Engineering, vol. 134, no. 2, pp. 1-8, 2008, doi: 10.1061/(ASCE)0733-9437(2008)134:2(129).

[10] S. E. N. Agustina, "Energy Analysis on Coal Steam Power Plant Pt. Energi Alamraya Semesta," B.S. Thesis, Agriculture Institute Bogor, 2012.

[11] L. Schibuola, M. Scarpa, and C. Tambani, "Variable speed drive ( VSD ) technology applied to HVAC for energy saving: an experimental investigation for energy saving," Energy Procedia, vol. 148, pp. 806-813, 2018, doi: 10.1016/j.egypro.2018.08.117.

[12] P. Bhase and M. Lathkar, "Energy conservation using VFD," Int. Conf. Energy Syst. Appl. ICESA 2015, no. January, pp. 531-536, 2016, doi: 10.1109/ICESA.2015.7503406.

[13] T. Aditya, "Research to study Variable Frequency Drive and its Energy Savings," Int. J. Sci. Res., vol. 2, no. 6, pp. 2319-7064, 2013.

[14] N. Khalid, "Efficient energy management: is variable frequency drives the solution," Procedia - Soc. Behav. Sci., vol. 145, pp. 371-376, 2014, doi: 10.1016/j.sbspro.2014.06.046.

[15] M. A. Magzoub, N. B. Saad, and R. B. Ibrahim, "Efficiency improvement of induction motor variable speed drive using a hybrid fuzzy-fuzzy controller," Energy Procedia, vol. 75, pp. 1529-1535, 2015, doi: 10.1016/j.egypro.2015.07.309.

[16] P. Shinde, R. Burungale, P. Kale, P. Jain, and A. Prof, "Speed Control of Induction Motor by Using Variable Frequency Drive," J. Eng. Res. Appl. www.ijera.com, vol. 4, no. 4, pp. 35-37, 2014.

[17] V. Ambrozic and I. Nastran, "Teaching Control of Electrical Drives - A Possible Approach," IFAC Proceedings Volumes, vol. 28; no. 18, pp. 159, 1995, doi: 10.1016/S1474-6670(17)45144-5.

[18] S. Tunyasrirut and V. Kinnares, "Speed and Power Control of a Slip Energy Recovery Drive Using Voltage-Source PWM Converter with Current Controlled Technique," Energy Procedia, vol. 34, pp. 326-340, 2013, doi: 10.1016/j.egypro.2013.06.761.

[19] M. K. Bairwa and G. K. Dalal, "Simulation Study of PWM Techniques for Voltage Source Converters," International Journal of Science and Research, vol. 4, no. 5, pp. 2460-2464, 2015.

[20] N. Pimkumwong, A. Onkrong, and T. Sapaklom, "Modeling and Simulation of Direct Torque Control Induction Motor Drives via Constant Volt / Hertz Technique," Procedia Eng., vol. 31, pp. 1211-1216, 2012, doi: 10.1016/j.proeng.2012.01.1166.

[21] P. Bhase and M. Lathkar, "Energy conservation using VFD," 2015 International Conference on Energy Systems and Applications, 2015, pp. 531-536, doi: 10.1109/ICESA.2015.7503406.

[22] E. F. O, O. E. E, O. J. C, and A. V N, "Modelling, Simulation and Performance Analysis of A Variable Frequency Drive in Speed Control Of Induction Motor," Int. J. Eng. Invent., vol. 3, no. 5, pp. 2278-7461, 2013.

[23] M. Subbarao, C. Sai, and S. Satyanarayana, "Design and analysis of variable switching frequency controlled integrated switched mode power converter for class C \& class D appliances," Ain Shams Eng. J., vol. 9, no. 4, pp. 2849-2858, 2018, doi: 10.1016/j.asej.2017.10.008. 
[24] D. Panasetsky, A. Osak, D. Sidorov, and Li Yong, "Simplified variable frequency induction-motor drive model for power system stability studies and control," IFAC-PapersOnLine, vol. 49, no. 27, pp. 451-454, doi: 10.1016/j.ifacol.2016.10.774.

[25] A. Saghafinia, H. W. Ping, M. N. Uddin, and A. Amindoust, "Teaching of Simulation an Adjustable Speed Drive of Induction Motor Using MATLAB / Simulink in Advanced Electrical Machine," Procedia - Soc. Behav. Sci., vol. 103, pp. 912-921, 2013, doi: 10.1016/j.sbspro.2013.10.413.

[26] D. A. B. Al-nimma and S. Williams, "Modelling a variable-frequency induction motor drive," Electr. Power Apl., vol. 2, no. 4, pp. 132-134, 1979, doi: 10.1049/ij-epa.1979.0021.

[27] C. Tan, et al., "Review of Variable Speed Drive Technology in Beam Pumping units for," Energy Reports, vol. 6, pp. 2676-2688, 2020, doi: 10.1016/j.egyr.2020.09.018.

[28] E. E. M. Mohamed and M. A. Sayed, "Matrix converters and three-phase inverters fed linear induction motor drives - Performance compare," Ain Shams Eng. J., vol. 9, no. 3, pp. 329-340, 2018, doi: 10.1016/j.asej.2016.02.002.

[29] F. Rey, P. Hokayem, and J. Lygeros, "Power Coordination in Variable Speed Drives using Model Predictive Control," IFAC-PapersOnLine, vol. 50, no. 1, pp. 3307-3312, 2017, doi: 10.1016/j.ifacol.2017.08.507.

[30] A. Kale, N. R. Kamdi, M. P. Kale, and P. A. A. Yeotikar, "A Review Paper on Variable Frequency Drive," Int. Res. J. Eng. Technol., vol. 4, no. 1, pp. 1281-1284, 2017.

\section{BIOGRAPHIES OF AUTHORS}

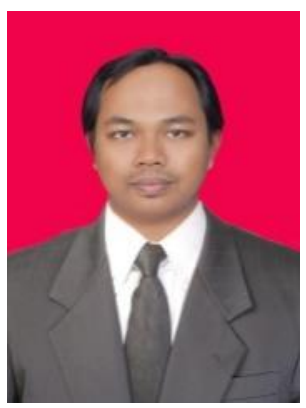

Pramono Mukti Wibowo was born in Jepara, Central of Java, Indonesia. Received a bachelor's degree in electrical engineering at Muhammadiyah University of Yogyakarta with a concentration in electrical. Now completing postgraduate studies at Sultan Agung University, Semarang. Email: pram.mukti@ std.unissula.ac.id

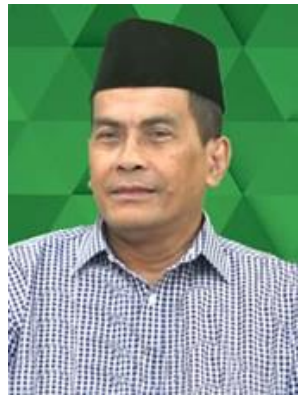

Muhammad Haddin a lecturer at the Faculty of Industrial Technology, Sultan Agung University, Semarang. Received a bachelor's degree in electrical engineering at Diponegoro University, a master's degree in electrical engineering at Gajah Mada University, and a doctoral degree at ITS Surabaya. Email: haddin@unissula.ac.id, Scopus Author ID: 55390711600.

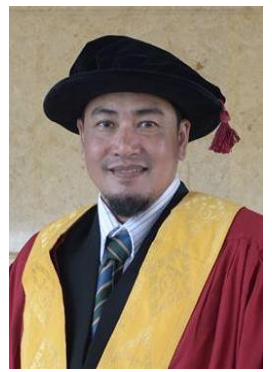

Arief Marwanto a lecturer in Faculty of Industrial Technology, Sultan Agung University, Semarang. He received a bachelor's degree at University of Muhammadiyah Yogyakarta, degree of master and phd at University of Technology Malaysia. Email: arief@unissula.ac.id, Scopus Author ID: 36023868500. 